Araştırma Makalesi, Gönderim Tarihi: 31.08.2020; Kabul Tarihi: 03.11.2020

\title{
How Can Behavioral Economics Contribute to Innovation? 5-Step-Method
}

\author{
Prof. Dr. Mustafa Şeref AKIN \\ Erzincan Binali Yıldırım Üniversitesi Iktisadi ve İdari Bilimler Fakültesi, \\ mustafa.akin@erzincan.edu.tr, Orcid ID: 0000-0002-1850-9118
}

\begin{abstract}
Behavioral economics has developed as an alternative view of the orthodox economy and has not seen the core stream in the innovation process. However, behavioral economics may actively contribute to new product development through its smart methods. This paper demonstrates how behavioral economics may contribute to the innovation process. The 5-steps method is developed: Business outcomes, personas, user needs, behavioral brainstorming, and hypothesizing. In a class activity, we test the process of learning management systems with students. The behavioral methods are explained. Team members interview with administrators, teachers, and students. They provide insights and ideas by realizing how behavioral economics has much to offer a business world in which most management ideas and best practices are freely available to be replicated and exploited. Managers now look to innovation as the primary source of differentiation and competitive advantage; they would succeed incorporating behavioral economics into the innovative process. In this paper, we particularly focus on the improvement of education quality through behavioral economics. The result we expect is both higher-quality knowledge transfer and reduce preparation time, permitting much earlier and better-informed contact with students.
\end{abstract}

Keywords: Behavioral Economics, Design Thinking, Innovation, Education, Behavioral Brainstorming, Method, App

Jel Classification: D9, D91 


\section{Davranışsal Beyin Fırtınası: Davranışsal İktisat İnovasyona Nasıl Katkıda Bulunabilir? 5-Adım-Metodu}

\section{$\ddot{O} \mathbf{z}$}

Davranışsal iktisat, ortodoks ekonomiye alternatif bir bakış açısı olarak gelişti ve inovasyon sürecindeki ana parçası olarak görülmemektedir. Bununla birlikte, davranışsal iktisatın akıllı yöntemleriyle yeni ürün geliştirmeye aktif olarak katkıda bulunabilir. Bu makale, davranışsal iktisatın tasarım odaklı düşünme ile birleşiminin inovasyon sürecine nasıl katkıda bulunabileceğini göstermektedir. Davranışsal iktisatçılar, bir inovasyon ekibine önemli faydalar sağlayabilir ve doğal bir üyesi olabilir. Bir ekonomistin başarısı davranışsal ilkeleri kullanarak, insanların ihtiyaçlarını keşfederek uygulanabilir bir iş stratejisiyle eşleştirerek müşteri değerini ve pazar fırsatını ortaya koymaktır. Bu amaçla 5 adımlı yöntem geliştirilmketedir: İş sonuçları, tipleme, kullanıcı ihtiyaçları, davranışsal beyin fırtınası ve hipotez oluşturma. Davranışsal iktisat, daha iyi bir işletme için bir çok fikir ve uygulama firsatı sunmaktadır. öneticiler artık inovasyonu farklılaşmanın ve rekabet avantajının birincil kaynağı olarak görmekteler; davranışsal ekonomiyi inovasyon sürecini dahil etmek için 5 adım modelini kullanabilirler. Bu makalede davranışsal iktisat yoluyla eğitim kalitesinin iyileştirilmesine özellikle odaklanılmaktadır. Beklenen sonuç, hem daha kaliteli bilgi transferi hem de hazırlık süresini kısaltarak öğrencilerle çok daha erken ve daha iyi bilgilendirilmiş iletişime izin vermektir.

Anahtar Kelimeler: Davranışsal İktisat, Tasarım Düşüncesi, İnovasyon, Eğitim, Davranışsal Beyin Fırtınası, Metod, Uygulama

Jel Sinıflandırması: D9, D91

\section{Introduction: Change}

Behavioral economics offers useful tools for change (Wendel, 2020: 10). Everywhere, we see problems that can be solved through innovation. Most innovation designs need a modification of attitude: quit smoking and keep a diet for longer life, use the online healthcare system, encourage people to save, and improve the communication between teachers and students. Those problems require behavioral approach to finding the solutions related to the design of a change. In this article, we will focus on the behavioral economics for contribution innovation system.

Thinking like a behavioral economist can transform the way we develop products, services, processes, and strategies (Heskett, 2017: 21). Low-cost, behaviorally informed changes can have outsized impacts (Ideas42, 2019: 1). We need to benefits insights from behavioral science to improve uptake and accessibility of vital services worldwide. 
The main problem is how to benefit from behavioral economics into the innovation process? Which model can be built for integration? Our paper suggests integrating behavioral brainstorming into a human-centered innovation process. Kelley and Kelley, 2013: 27-30; Wrigley, 2016: 149, Poggenpohl, 2017: 255). The power of design thinking and behavioral economics lies in understanding what users need and builds a new choice architecture around their decisions' moments. We apply behavioral economics to identify and tweak pivotal moments of decision making to increase our design's success exponentially (Bridgeable, 2017: 1).

There were thoughts and attempts to realize it (Lissack, 2019: 232; Rankin, 2019: 376; Bridgeable, 2017: 1). Most of these works cover design thinking and behavioral economics without building a methodology (Madrian, 2014: 663; Soman, 2015: 4). Some behavioral consultant firm applies methods without revealing the process (Behavioral Insights Team, 2018: 1; TGG Group, 2018:1; FehrAdvice \& Partners. 2018: 1; BEworks, 2020: 2). The design firm Bridgeable and the behavioral economics center at Duke University Common Cents Lab develop Behavior Change Framework (BCF), which is a tool for integrating behavioral economics into the design process (Bridgeable, 2017: 2). However, their model is incomplete and confusing for integration. $\mathrm{BCF}$ is incomplete since it mentions but does not integrate a process with a full method. However, we use the 5-step method for the integration: Business outcomes, personas, user needs, behavioral brainstorming, and hypothesizing. It is confusing since BCF does not identify which behavioral economics methods are suitable for a change. We suggest organizing a brainstorming session to overview behavioral methods to encounter different opportunities.

In this article, we tested the behavioral economics on how we might help teachers engage their students more, organize the curriculum, and ensure that all students are on track in a classroom exercise. We follow a similar method of Daly, et.al. (2012: 601) and Seifer et al (2016:7). They showed the students design methods and apply in one case. We explain the behavioral economics methods and ask college students to interview students (as well as each other's), teachers and administration for insights. We aim to build an app to assist administration, teachers and students in communicating and monitoring and organizing classes.

\section{Literature}

\subsection{Behavioral Economics}

Behavioral Economics aims to understand how people decide through psychology and social psychology for commercial and welfare purposes. Contrary to conventional economics, behavioral economists believe that people have limited power and may act irrationally (Simon, 1976: 7).

Behavioral economics rejects the rational assumptions of classical economics. In classical economics, man is brilliant and possesses all information. Man can solve a 
very complex problem in a short time, like a supercomputer. However, people can't have all the information. They do not think independently from emotions, calculate every risk, and be consistent in all their actions (Ariely, 2011: 10-20). They are emotional. The environment affects decision making and behavior.

In the classical economics perspective, people do nothing to hurt themselves. Smarter decisions are made when slowing down thinking and behavior and reviewing them with a calm mind. However, our brain capacity does not allow us to dive deeply in every moment. Therefore, habits play an essential role. It is a habitual way to memorize quickly without tiring the brain. We overestimate our capabilities. We make plans about our goal, and we continuously fail in estimating timing (planning fallacy) (Connolly and Dean, 1997: 1029). Behavioral economics forms the strategy of these decision processes of people. Acquiring good habits ensures that desired results are achieved.

Behavioral economics develops a change mechanism by constructing the choice architecture to increase well-being and efficiency on an individual, society, and company (Thaler and Cass, 2009: 25-35).

Four strategies can be applied for behavioral changes: i) Legal (rules and regulations), ii) Economic (implementing rewarding and punishing incentives for people), iii) Marketing (persuading people with information), iv) Behavioral economics (making it easy for people to do what they want through choice architecture and convert it a habit).

It cannot be assumed these four strategies separate from each other. Here, the preference for behavioral economics and neglect of others is not emphasized. There are not three strategies against behavioral economics. But by the right combination of these strategies, successful results are obtained with extraordinary productivity increases. Behavioral economics and other persuasion methods are complementary. For example, unless person is informed by marketing (marketing), he cannot go into automatic (behavioral economics) behavior mode in the long term. The brain resists new behavior acquisition eventually when it does not accept. In behavioral economics, reorganizing the options and environment is essential. It is assumed that the person is already convinced about the behavior change but cannot act due to various obstacles. Intentions cannot turn into action.

Though building the choice architecture, we identify the friction can be deterred from taking action by small barriers. In the choice of architecture, when there is uncertainty (Samson, 2014: 1) setting defaults is an effective method. Default options are a pre-set decision that takes effect if nothing is identified by the decision-maker (Johnson and Goldstein, 2003: 1338). Our decisions are influenced by how choices are framed. It is context-dependent (Kahneman and Tversky, 1979a: 263). We are bounded with our previous decisions through status quo bias (Tversky and Kahneman, 1974: 1124). Judgment The initial choice influences subsequent decisions (anchoring principle) (Tversky and Kahneman, 1974: 1124) . Our identity, regardless of cost- 
benefit analysis of our decision, plays a significant role (Shih et al., 1999: 20). Even small friction can stop our welfare (Bettinger et.al., 2012: 1).

Changing people's perceptions of what 'social norm' is can lead them to behave differently (Schultz et.al., 2007: 5). Willpower, time preferences, emotional abilities, and social preferences can influence on our decisions (Banerjee,1992: 797; Bikhchandi et al., 1992: 992). We consider the framing of the situation to change our perception (Kahneman and Tversky, 1979b: 70; Roland et al., 2012: 1).

Emotional and mental resource burdens result in diminished motivation, increased distractibility, changes in information processing, and a more miserable mood. Fatigued participants are more likely to fail to detect errors and less likely to take remedial action and are more willing to take chances in everyday decision making. Such general deficits can easily lead to diminished performance (O'Dhaniel et al., 2015: 9).

In some choice architecture, asking people to plan and set goals can lead people to follow through on their intention to perform better. Sending a well-timed and straightforward reminder an cause more people taking action (Mullainathan and Shafir, 2009: 121). Shortening the feedback on how people are performing can have dramatic impacts on their decision-making (Keller et al., 2011). When they perceive progress, they are more eager to finish (Zhou and Soman, 2003: 517).

We experience the pain of paying because we are loss averse. People prefer credit cards over cash since the depletion of resources (money) is less visible pain, and payment is deferred (Rick et al., 2008: 767; Thomas et al., 2011: 505). This pain is reduced in credit card purchases because the plastic card is less tangible than cash.

\subsubsection{System 1 and System 2}

There are two types of working models of the brain (Kahneman, 2013: 10-20). System 1 is emotional, automatic, fast, and deliberately performs behavior (for example, without thinking about shifting gears while driving). It assesses the situation using past experiences and practical methods. Our emotions and feelings connect with our bodies and become a habit (Damasio et al., 1996: 499). System 1 gives generally positive results in cases of familiar or similar but does not work well in an unfamiliar situation.

System 2 is our conscious state. It is slow, focused, aware, awake, and thinking. It rationally analyzes unfamiliar situations and solves complicated problems. However, there is a limit to the ability and capacity of system 2 to investigate. It is difficult for the memory to hold a 10-digit number. While trying to keep the 10-digit number, the system cannot perform other cognitive tasks. Therefore, he must rely on system 1 to perform the task automatically for other jobs (Kahneman, 2013: 10-20).

The human brain is unsuccessful in finding the right choice for complicated and more options. It needs less choice and organizing them too. The brain has limited 
capacity. Otherwise, it will collapse on excessive options and paralyzes (Iyengar and Lepper, 2000: 995)

Our conscious intelligence only comes into play in a new situation. Therefore, habits and short cut responses created in system 1 have an essential place in the planning of alternative architecture. System 1 tools are habits, references, socially endorsed, and intuitive thinking (Newell and Simon, 1972: 20-30; Ariely, 2013: 7-17).

Human brains are finding short-cut solutions against complicated problems (Ariely, 2013: 30-40). Because we have limited cognitive intelligence (Simon, 1976: 15-20). System 1 saves system 2 to have free space to calculate. It solves the problem more easily and quickly. It simplifies the problems for us. The simplification process can also lead us in the wrong direction.

When the wrong decisions made by people are questioned, it is seen that people are not rational, they continue to make systematic mistakes, and they act against their interests.

Behavioral economics is the construction of choice architecture through system 1 and 2 to increase economic and social welfare (BEworks, 2020: 1). More openly, we build a choice architecture to retain consumer sovereignty (the right to choose) but nudging consumers to make certain choices (Thaler and Cass, 2009: 20).

One solution that the brain finds against the complicated problems of life to take advantage of system 1 is to see what other people are doing and repeat the same. Social approval is to confirm the accuracy of a product or action with the behavior of people similar to our social status, which we think is like us. The act approved by the social group is taken granted (Cialdini, 2001). Our role as a behavioral economist is to improve the mechanism of social approval.

We prefer to believe the benefits of a product and buy it according to expert advice (Till and Busler 1998). However, if we genuinely think (system 2 activity), the expert has economic benefits and conflicts of interest due to the recommendation of this product.

\subsection{Behavioral Brainstorming}

For a better understanding of the behavioral brainstorming, we need to cover the difference between random cross-pollination and designated cross-pollination methods.

\subsubsection{Random Cross-Pollination}

In random cross-pollination, seemingly unrelated concepts emerge to our problem (concept/product) to find a new idea. We define the problem. We randomly look or imagine what we have in our surroundings or our minds. We ask how this 
item/notion may help to solve the problem in terms of its shape, color, functions, emotions, and sounds. We discuss how new ideas can solve the problem (de Bono, 1992: 20-30). For example, we ask the group of brainstorming what they see in our surroundings. One member sees the book. What are the features of a book? A book has a rectangular shape, white, colorful cover, categorize information, pictures, explains design topic, demonstrates facts, the richness of knowledge, reading lines, enlightening people, civilization, and a quiet place. What features of this book: It is a design book that covers castle, cat, panda, monster, child, and instinct pictures. What do the notions of rich, quiet, facts, lines, and panda can contribute to our problem? Being rich may invoke success, which can contribute to finding a solution. Being quite may give us peace. It is a random process and helps us to think differently.

\title{
2.2.2. Designated Cross-Pollination
}

The designated cross-pollination captures the existing list of solutions to help the team produce new ideas. Through theoretical and empirical works, a list of solutions is gathered to apply new problems (Seifer et al., 2016: 20-30) Each solution/concept offers new possibilities. Behavioral brainstorming is a form of designated cross-pollination.

A team uses design heuristic, seventy-seven design solutions collected to develop a new product or extend existing products (Daly, et.al. 2012: 601) The concepts include durable, non-durable consumer products, sustainability, and geometric modification.

A design heuristic through sustainability includes material reduction, recyclable materials, packages as functional components, and human-generated power (Table 1). The function component guides designers to benefit packages as a part of the product. A packaging of pencils is adjustable so it can serve as a holder for them (figure 1) (Seifer et al., 2016: 30-35)

\section{Figure 1 Use Packaging}

\section{USE PACKAGING AS FUNCTIONAL COMPONENT}

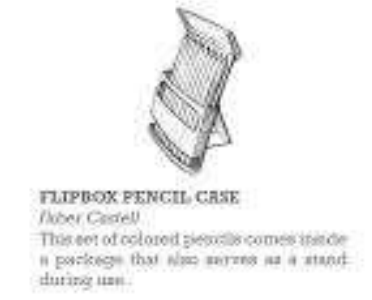

Source: (Seifer et al., 2016)

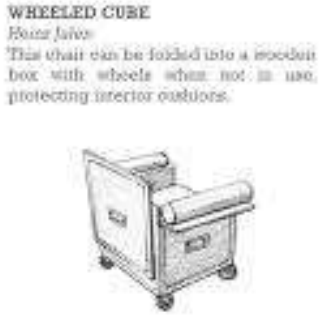

)


How Can Behavioral Economics

Table 1. Examples from 77 Design Heuristic

\begin{tabular}{lll}
\hline 71 & $\begin{array}{l}\text { Use different energy } \\
\text { source }\end{array}$ & $\begin{array}{l}\text { Replaceable expected energy source and } \\
\text { redesigned. } \\
\text { geothermal, hydroelectric, solar and wind }\end{array}$ \\
\hline 72 & $\begin{array}{l}\text { Use human-generated } \\
\text { power }\end{array}$ & $\begin{array}{l}\text { Make the user act as the power source for both } \\
\text { primary and secondary functions, and the synthesis } \\
\text { of multiple energy sources. }\end{array}$ \\
\hline 73 & $\begin{array}{l}\text { Use } \\
\text { components for use }\end{array}$ & $\begin{array}{l}\text { Identify the core function of the product and use } \\
\text { multiple components to achieve the same function } \\
\text { with components specialized in tools }\end{array}$ \\
\hline
\end{tabular}

Source: (Daly, et.al. 2012: 601-609)

Similarly, the behavioral thinking list organized by Common Sense Lab (a behavioral economics lab) directed by a prominent behavioral economist Dan Ariely presents solutions for behavioral problems (Bridgeable, 2017: 2) However, behavioral economics does not develop a model for user need research, hypothesizing, prototyping and iteration (Poggenpohl, 2017: 255). Combining these two human-centered approaches, we develop the model for change/innovation.

\subsection{Public School and Behavior Economics}

Some students see school diplomas as a requirement rather than a support in their careers. It may even be undesirable since a lack of a diploma is often a symbol of the beginning of success stories (i.e., owners of Facebook, Microsoft). School-work conflict is about more than status. Loss of time, increased risk of unnecessary knowledge, higher rates of unemployment, and anxiety: These are just a few of the long-term consequences of schooling that can cause education challenges.

Pisa, an international education exam, reveals that fifteen-year-old student stagnate in reading and mathematics, even as the country has spent billions to close gaps with the rest of the world (Goldstein, 2019; BusinessInsider, 2016: 1). According to the 2018 (latest) results of a rigorous international exam, the performance of teenagers in reading and math has stagnated since 2000 , despite decades of effort to raise standards and help students compete with peers around the world (Barshay, 2019).

Low-performing students were the focus of decades of bipartisan education overhaul efforts, costing billions of dollars, resulting in a string of national programs No Child Left Behind, Race to the Top, the Common Core State Standards, the Every Student Succeeds Act — but uneven outcomes (Goldstein, 2019). 1.2 million students drop despite significant efforts by educators and leading educational institutions (Miller, 2015). A high school dropout will earn $\$ 200,000$ less than a high school graduate over his lifetime and a million dollars less than a college graduate (Cheeseman et al., 2014). 
What needs to change in educational quality (American Achivers, 2016: 1; BusinessInsider, 2016: 1)? Why hasn't there been more progress in students' education and what would a behavioral solution look like that could meet both teachers' and students' needs? What explains the gap between teachers' and students' desire to study space and unlimited reaching and their lack of utilization of user experience software services? Behavior is a critical part of the answer. This includes measurable behaviors in teachers and students, their organization schedules and management of classes, and their hopes and dreams.

Wherever teachers interact with students - from curriculum to pre-K programs and tutorial services - behavioral science can provide insights to help (public) education institutions to build better outcomes and experiences. The effectiveness of education policies, programs, and places depends on how students and teachers respond to and use them.

\section{Methodology: Integrated Method and Its Steps:}

Innovation models follow a similar pattern: understanding (ethnographic)generation (brainstorming-)-testing (prototyping). We may explore behavioral economics as the integration of ethnographic, brainstorming, and prototyping methods to support innovation processes (Kumar, 2012: 5-25, Luma Institute, 2012: 10-30, 2014: 17, Lietdka et al., 2014: 56-66; Seidel and Fixson, 2016). Seidel and Fixson (2013, 2016) already stated that there are essentially three main tools in DT: need-finding, brainstorming, and prototyping. The first phase is ethnographic. Understanding what users want is the basic need for companies that want to survive and advance in the sector. The main reason for the development or application of ethnographic techniques is that $80 \%$ of the products put on the market fail within six months (Zaltman, 2003). The costs of such failures are very high: loss of income, low customer satisfaction, and poor employee morale (Zaltman, 2003: 40-60). We benefit from interview to identify the user's inner world. In the second stage, we brainstorm by using behavioral economics to generate ideas and solutions to put forward against the current status quo. In the third stage, we test our prototype with stakeholders by building a hypothesis.

In figure 2, an explanation for each method used is provided. We use process 5step methods combining design thinking and behavioral economics: Business outcomes, personas, user needs, behavioral brainstorming, and hypothesizing.

\section{Figure 2. Methods}

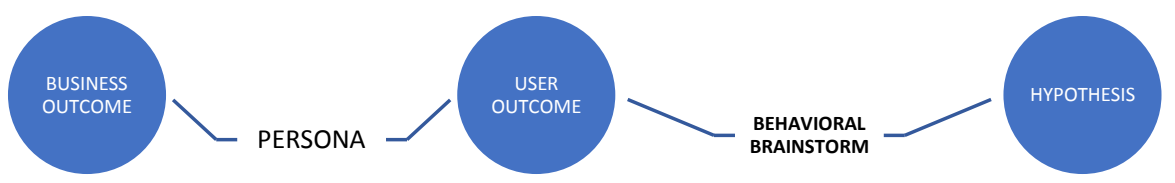

Step 1-Business Outcome 
At step 1, we are expecting a group of firm representatives to answer what outcomes might be identified and measured at the end? What does success mean to them?

\section{Step 2-Personas}

Persona, at the human center design, is to create reliable and realistic representations of key audience segments for reference (Luma, 2012). We list potential customers in step 2. As a group, they brainstorm potential target groups relevant to their product or service. We select one or two target personas. Before preparing personas, members of groups interview with likely personas.

\section{Step 3- List Potential User Needs:}

At step 3, we brainstorm potential user needs relevant to their products or service for each persona.

\section{Step 4 Behavioral Brainstorming}

At step 4, we intensely use behavioral economics for sparking new ideas at the intersections of distinct categories. We provide a list of behavioral methods which derive from the Common Cents Lab list (Annex Table 1).

\section{Step 5- Hypothesis}

At step 5, a short sentence, we summarize the fundamental hypotheses of a proposed solution is to test with stakeholders by combining the insights we collect at previous steps. We are also using hypotheses to build prototypes and to measure our success goals. We write the hypotheses statements based on this format:

This (business outcome) will be achieved if (these users) attain (this user needs) with this (behavioral feature).

We build prototypes to test the hypothesis. The goal of prototyping is to learn about the strengths and weaknesses of the idea and to identify new directions that further prototypes might take.

\section{Findings}

Our team members are to learn why most students do not communicate with their teachers online. Hierarchal relationship, the stress of perception (i.e., avoid silly questions), the complexity of the application, and the lag of response time impede communication of teachers and students. So, we aim to define communication and develop strategies to identify safe contexts to ask, and a reference behavior to promote students to ask teachers. 
We delve into the root causes of school-work conflict from a behavioral perspective - and offer potential solutions. We investigate opportunities for behavioral design to improve learning engagement at the teacher-student relationship. We identify and implement behaviorally-informed solutions to increase student participation, responsibilities of teachers, uptake of teaching services, and involvement in learning activities. The public education provider seeks to improve the overall quality of both students' and teachers' experiences.

We identify behavioral bottlenecks that hinder students' engagement with educational programs. We aim to design across a wide range of learning issues, including in business outcomes and user outcomes.

We explore the barriers preventing students and teachers from engaging. These challenges include external hassles, such as figuring out where to fill a registration form to get engaged UX (user experience), and internal psychological forces, such as feeling that asking isn't right for me.

Building on our formative work in student learning, we design the learning management system (LMS) to highlight the K12 excelling in student learning and engagement.

With a better understanding of the conditions that create school-work conflict, we can address them. Our designs range from creating new educational policies and practices to using software.

Our work is a plan on groundbreaking, evidence-based innovations to extend behavioral science innovations across an array of public programs and processes. We will redesign the UX platform to make teachers and students easier to understand, increase access to online tutorial aid, boost school persistence at schools, and will design an inexpensive way to reduce teaching wastage by helping improve adherence to online resources during, before and after the class.

\section{Step 1}

At step 1, we ask the administration about their expectations. We organize the brainstorming session for the business outcomes by identifying four clusters; acquisition, activation, retention, referral (figure 3). 
How Can Behavioral Economics

\section{Figure 3}

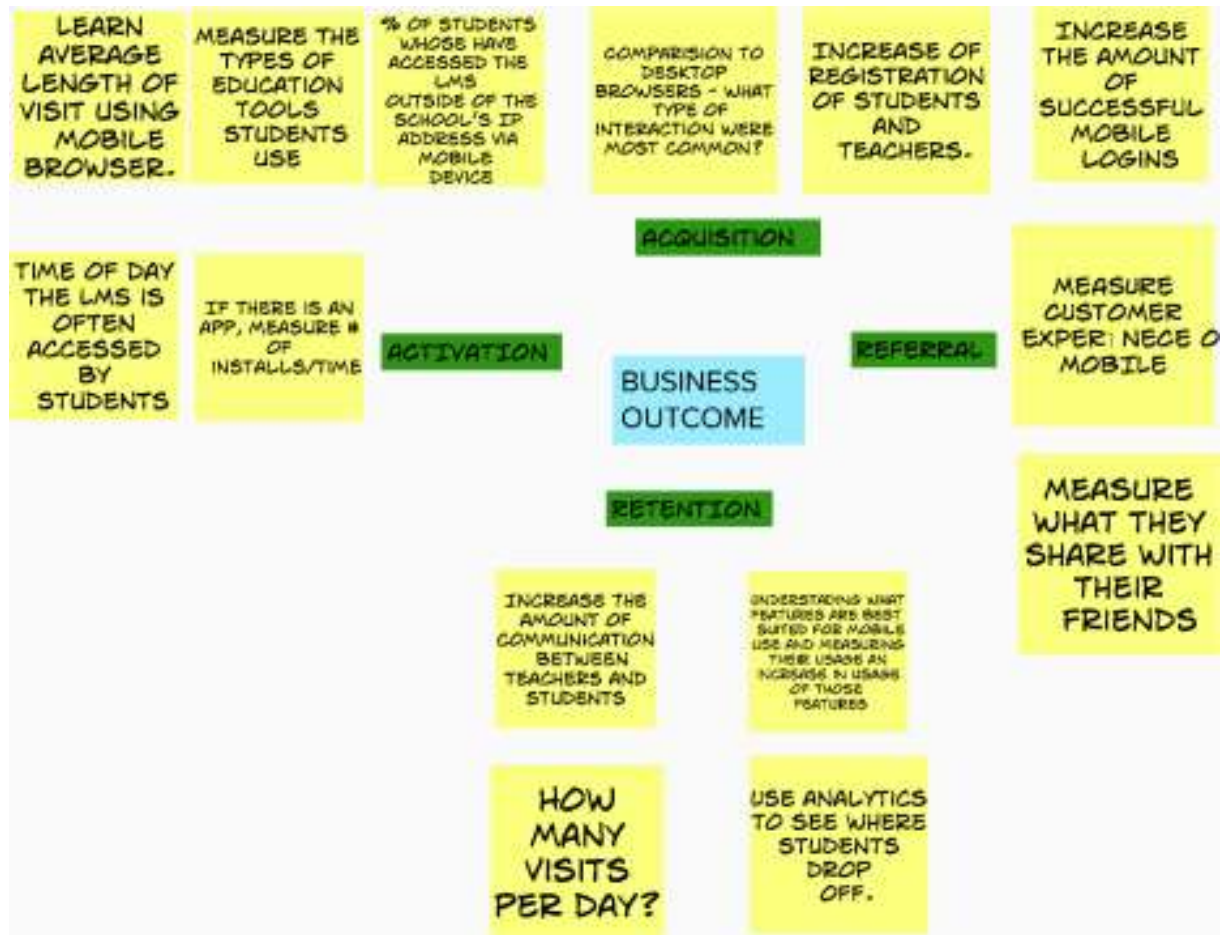

\section{Step 2}

At step 2, the team lists potential customers at table 2 and reviews likely personas from education administrators to busy parents.

Table 2. Potential Personas

\begin{tabular}{|l|}
\hline Education administrator \\
\hline k-12 students \\
Middle school teachers (6-8) who is familiar with mobile devices in passing and \\
able to type and spell \\
\hline Remote learning student \\
High school student- Sarah, 15 years old, uses a smartphone, tablet and needs \\
guidance. \\
\hline International student- users tablet to call home on skype \\
\hline Brian, 12 yo., LA suburbs. Entry-level Android phone \\
\hline Remote learning instructor
\end{tabular}


Davranışsal Beyin Fırtınası: Davranışsal İktisat $\underline{\text { AKIN }}$ İnovasyona Nasıl Katkıda Bulunabilir? 5-Adım-Metodu

Ted is reluctant to call parents except for major issues but wants to manage expectations and update them on student progress

Rich kid with all the gadgets

School district superintendent needs an overview of student performance so he can anticipate school performance on standardized tests

A busy parent on the go but need a track of their child's progress (or the lack thereof)

The team members identify the target personas. We focus on the most relevant ones: "student" Sarah and "teacher" Ted. We interview and participate in class activities. We fill out the personas (table 3). We recognize the functional needs (easy to access, keep on track, get good grades) and emotional needs (proud, recognition) of Sarah and Ted.

Table 3. Personas: Sarah and Ted

\section{Sarah-Student}

Main sentence: 'I don't have enough time for assignments and exams.'

Fifteen years old teenager from northeastern. She has an iPhone. She meters social media sites like Facebook and likes to share her updates. She is an average student but wishes to succeed in the exam. She is nervous testing. She does not like to share her progress and results with her friends. She engages in post-school activities. She carries her phone at home around the house.

Her obstacle is hard to get the impact of the lesson on a small device. Her difficulty is to understand the topic, focus on assignments, and prepare for the exam. She procrastinates her duties. She wants to know how she did on her most recent homework but prefers to be notified instead of checking the results repeatedly. She wants to ask questions at odd, but she is shy. She wants to have a brilliant career. She also desires that her parents are proud of her.

\section{Ted- teacher}

Main sentence: "I am doing an important task."

Thirty-four years old graduate is from a small college in NY.

$\mathrm{He}$ is a married guy with one girl. He is a hobbyist programmer and technical savvy.

$\mathrm{He}$ is the math teacher with seven years of experience in teaching. He is passionate about education, and he is on a mission. After work, he exercises and going to meet with his friends. As a tech-savvy, he uses social networks but prefers email for communication.

He wants to check in with students submitting their work. He hopes to respond to last-minute student questions. He needs to track student progress. He prefers to notify parents and administrators if there is an issue with a student. He would like to provide individual feedback and support to each student. He needs to know if most students do not understand the lesson so he can review it again. He wants to be on track with the curriculum during the lesson. Sometimes, he moves away from the curriculum. He does 
How Can Behavioral Economics

not want to be bombarded by student communications. He just wants to make one pass at night.

He wants to get rewarded with the best teacher title and be recognized by his excellence and dedication.

\section{Step 3}

At step 3, we list potential user outcomes. We cluster students' needs in 3 groups: organization (identify areas that can be improved and provide tools to do so, turn in her work and know it was done on time, spend less time doing homework), communication/ notification (how she is doing compared to her classmates, what she can do to improve her grades), expectations (appreciated by her parents, make her parent proud of her, have high grades so she can choose preferred education later on) (figure 4).

\section{Figure 4. User Needs/Student/Sarah}

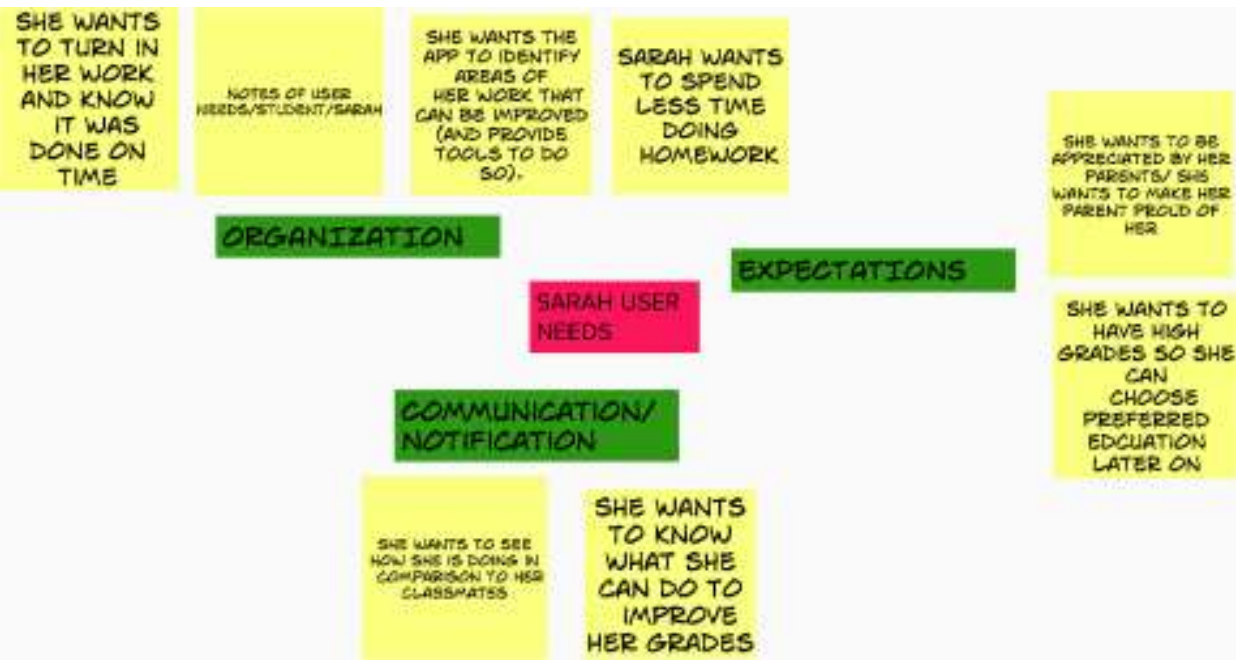

We cluster teachers' needs in three groups: student monitoring and communication hopes and dreams, classroom management (figure 5). 


\section{Figure 5. User Needs/Teacher/Ted}

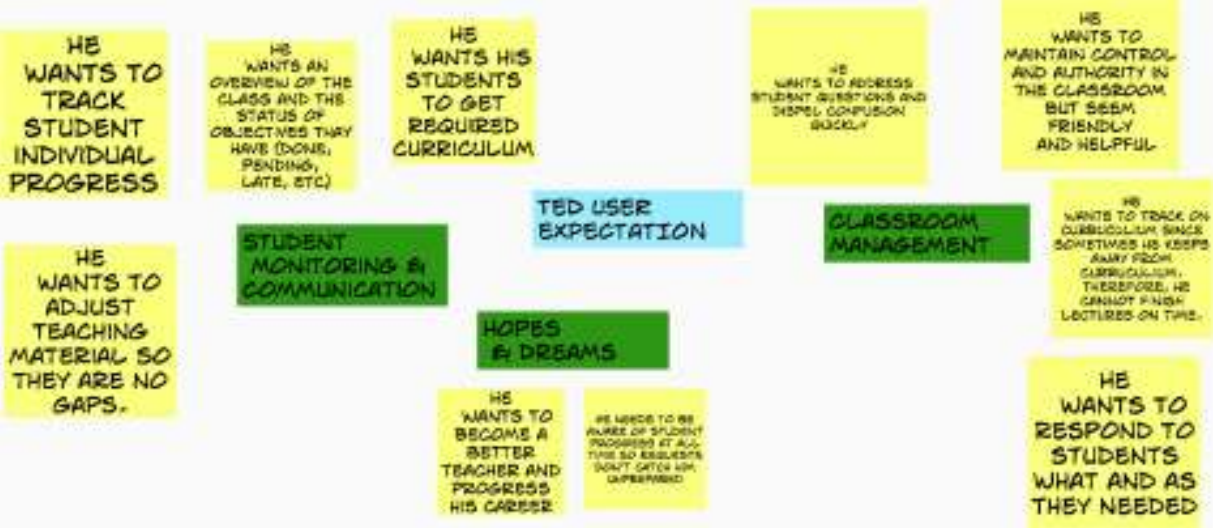

\section{Step 4}

At step 4 (behavioral brainstorming), we benefit many ideas driven by the behavioral methods (annex table 1). For business needs, in the acquisition cluster, we suggest the default method, so registration class requires to sign learning management system. At the student side, in the communication/notification cluster, we anchor the success bar so students and teachers collaborate to attain it. At the teacher side, in the student monitoring and communication category, we allow teachers to send the assignments in a pre-determined schedule (default bias) one by one to prevent the decision paralysis (table 4).

\section{Table 4. Behavioral Brainstorming for Business}

\begin{tabular}{|l|l|l|l|}
\hline Methods & $\begin{array}{l}\text { Business Outcome } \\
\text { Acquisition }\end{array}$ & $\begin{array}{l}\text { Sarah User Needs } \\
\text { Communication/ } \\
\text { Notification }\end{array}$ & $\begin{array}{l}\text { Ted User Needs } \\
\text { Student Monitoring \& } \\
\text { Communication }\end{array}$ \\
\hline Anchoring & $\begin{array}{l}\text { Inform students what } \\
\text { the required amount of } \\
\text { time is needed to } \\
\text { succeed at the exam. } \\
\text { (i.e., the excellent } \\
\text { student finishes 20 } \\
\text { questions at 15 min.) }\end{array}$ & \\
\hline Availability Bias & & & $\begin{array}{l}\text { Students may only see } \\
\text { one assignment. }\end{array}$ \\
\hline Confirmation Bias & & $\begin{array}{l}\text { Schedule the class } \\
\text { materials and teaching } \\
\text { time and send signal for } \\
\text { the transition from one }\end{array}$ \\
\hline
\end{tabular}


How Can Behavioral Economics Contribute to Innovation? 5-Step-Method

\begin{tabular}{|c|c|c|c|}
\hline & & & $\begin{array}{l}\text { subject to another } \\
\text { subject through a light } \\
\text { flash. }\end{array}$ \\
\hline Default Bias & $\begin{array}{l}\text { All students should sign in } \\
\text { to LMS for registering the } \\
\text { class. }\end{array}$ & & 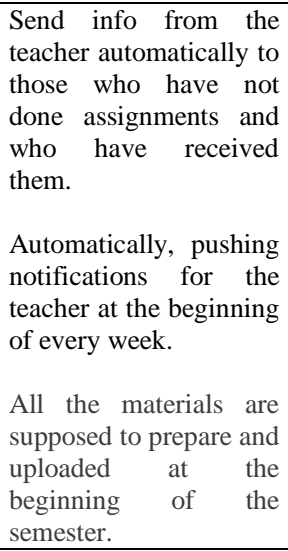 \\
\hline \multicolumn{4}{|c|}{ Disposition Effect } \\
\hline \multicolumn{4}{|c|}{ Ego Depletion } \\
\hline \multicolumn{4}{|c|}{ Endowment Effect } \\
\hline Friction Costs & $\begin{array}{l}\text { An easy registration } \\
\text { system: just name, id } \\
\text { number, email address and } \\
\text { password. }\end{array}$ & $\begin{array}{l}\text { Allow students to } \\
\text { automatically } \\
\text { their entries. }\end{array}$ & $\begin{array}{l}\text { An easy tracking } \\
\text { system for students: just } \\
\text { names and grades. }\end{array}$ \\
\hline \multicolumn{4}{|l|}{ Gamification } \\
\hline Goal Gradient & & & $\begin{array}{l}\text { Tracking/Showing each } \\
\text { student's progress over } \\
\text { time, in comparison to } \\
\text { the class. }\end{array}$ \\
\hline \multicolumn{4}{|l|}{ Herding } \\
\hline \multicolumn{4}{|c|}{ Hyperbolic Discounting } \\
\hline \multicolumn{4}{|c|}{$\begin{array}{l}\text { Identifiable Victim } \\
\text { Effect }\end{array}$} \\
\hline $\begin{array}{l}\text { Implementation } \\
\text { Intentions }\end{array}$ & $\begin{array}{l}\text { Create a compulsory } \\
\text { tutorial week for teachers } \\
\text { and students at the } \\
\text { beginning of the year. }\end{array}$ & & $\begin{array}{l}\text { Show the students' } \\
\text { progress with numbers, } \\
\text { lines, and color. } \\
\text { Compare the assigned } \\
\text { goals and situation of a } \\
\text { student in terms of } \\
\text { quantitative and } \\
\text { qualitative goals. }\end{array}$ \\
\hline \multicolumn{4}{|c|}{ Lack of Self-Control } \\
\hline \multicolumn{4}{|c|}{ Loss Aversion } \\
\hline \multicolumn{4}{|c|}{ Mental Accounting } \\
\hline \multicolumn{4}{|l|}{ Money Illusion } \\
\hline Omission Bias & & $\begin{array}{l}\text { LMS shows what the } \\
\text { approaching events } \\
\text { (exam, assignments, } \\
\text { classes...) }\end{array}$ & \\
\hline
\end{tabular}


Davranışsal Beyin Fırtınası: Davranışsal İktisat İnovasyona Nasıl Katkıda Bulunabilir? 5-Adım-Metodu

\begin{tabular}{|c|c|c|c|}
\hline $\begin{array}{ll}\text { Opportunity } & \text { Cost } \\
\text { Neglect } & \\
\end{array}$ & & & \\
\hline \multicolumn{4}{|l|}{ Optimism Bias } \\
\hline \multicolumn{4}{|l|}{ Ostrich Effect } \\
\hline \multicolumn{4}{|l|}{ Overconfidence } \\
\hline \multicolumn{4}{|l|}{ Pain of Paying } \\
\hline \multicolumn{4}{|l|}{ Payment for Effort } \\
\hline Planning Fallacy & & $\begin{array}{l}\text { Send a systematic } \\
\text { reminder about the } \\
\text { duties }\end{array}$ & \\
\hline Power of Free & Inform that this is free. & & \\
\hline Pre-Commitment & & & $\begin{array}{l}\text { Ask each student about } \\
\text { the grade they hope and } \\
\text { commit in the } \\
\text { beginning of the } \\
\text { semester. }\end{array}$ \\
\hline \multicolumn{4}{|l|}{ Reciprocity } \\
\hline \multicolumn{4}{|l|}{$\begin{array}{ll}\text { Regret } & \& \\
\text { Counterfactuals } & \\
\end{array}$} \\
\hline Relativity & & & $\begin{array}{l}\text { Compare students with } \\
\text { other students }\end{array}$ \\
\hline Reward Substitution & & & $\begin{array}{l}\text { Inform teachers how } \\
\text { the } \\
\text { performance increase } \\
\text { overtime. }\end{array}$ \\
\hline Scarcity Mindset & $\begin{array}{l}\text { There is a limited place in } \\
\text { class registration. }\end{array}$ & & \\
\hline \multicolumn{4}{|l|}{ Self-Herding } \\
\hline \multicolumn{4}{|l|}{ Self-Signaling } \\
\hline Social Proof & $\begin{array}{l}\text { Inform that every student is } \\
\text { registering. }\end{array}$ & & $\begin{array}{l}\text { At the training week, } \\
\text { show how much } \\
\text { technology prevails and } \\
\text { how much students } \\
\text { need the new learning } \\
\text { technology in their } \\
\text { career }\end{array}$ \\
\hline Status Quo Bias & $\begin{array}{l}\text { If this is registered } \\
\text { students/teachers/parents } \\
\text { and automatically register } \\
\text { for the new classes. }\end{array}$ & & \\
\hline \multicolumn{4}{|l|}{ Substitution } \\
\hline \multicolumn{4}{|l|}{ Tunneling } \\
\hline \multicolumn{4}{|l|}{ What-the-hell Effect } \\
\hline $\begin{array}{l}\text { You Are What You } \\
\text { Measure }\end{array}$ & & & \\
\hline
\end{tabular}

Note: The behavioral ideas for each cluster exists and may request from the author.

\section{Step 5}

At step 5, we write hypotheses statements based on table 4. We combine business outcomes, personas, users' needs, and behavioral ideas. We use this format for coherence: This (a-business outcome) will be achieved if (b-these users) attain (c- 
How Can Behavioral Economics Contribute to Innovation? 5-Step-Method

this user need) with this (d- behavioral feature) (table 3). Some examples are given in table 5 .

\section{Table 5. Hypothesizing}

This (a-business outcome) will be achieved if (b-this user) attains (c-this user needs) with this (d- behavioral feature)

Registrations will be attained $100 \%$ (a) if student Sarah (b) attains a quick sign up process attached to class registration $(d)$ at the beginning of the semester.

Increased time using the software application one hour a day (a) will be achieved if student Sarah (b) sees how she is doing (c) with the ability to track progress (d).

We will increase communication between the teacher, Ted and the student, Sara (a) if the teacher, Ted (b) sends a ready-made question, receive responses of Sarah and feedbacks to her quickly $(d)$ so students will ultimately improve their performance by $50 \%$ from 6 mistakes out of 40 items to 3 mistakes out of 40 questions (c).

\section{Conclusion}

This article explores how to design for behavior change by leveraging behavioral economics. We use the 5-step methods when designing a product or service that requires users to change (or do something). This might mean developing to help users adhere to their daily heart medication, follow through on saving money from each paycheque or choose a healthy option from the lunch menu. The framework will be most handy when we are ready to design features at the touchpoint level.

In this paper, we particularly focus on the improvement of education quality through behavioral economics. The result we expect is both higher-quality knowledge transfer and reduce preparation time, permitting much earlier and better-informed contact with students.

In our case, we recognize that teachers and students have many needs from the class and assignment management to in-depth emotional expectations about recognition and appreciation.

Behavioral insights can be used not only to impact submitting behavior but to increase learning engagement overall. Thanks to supporting the list of principles, we work to identify specific barriers to different avenues of learning engagement and design innovative and evidence-based solutions to them.

We aim for a behavioral method that integrates user experience and education to meet their learning management needs and the needs of educational providers. Disconnected students and teacher's relationships need solutions explicitly designed to help them manage the students' age psychology and learning abilities. Reaching 
educational stability requires a product that will detect and intervene in lowperformance time.

Our new proposed solution would enable students' educational provider benefits in four major ways: automating registration and learning schedule, offering a different level of lessons, tracking (and comparing) the performance, and integrating learning curriculum (and course materials) that teachers and students can reach anytime and anywhere. We use parents as a surveillant, along with behavioral enhancements like smart reminders and a peer structure that will be effective in our project proposal to educational institutions. In these suggestions, we build new procedures that teachers automatically send information through LMS. They can input student information throughout each class (rather than scrambling at the end of the semester to pass it on).

Over the next years, we hope that many design thinkers and behavioral economists apply their expertise in cutting-edge behavioral interventions to services and products in helping institutions and individuals plan and change for the future.

\section{References}

American Achievers (2016). ExcelinEd and America Achieve Course Unlocks PISA Data for Districts. http://americaachieves.org/excelined-and-america-achievescourse-unlocks-pisa-data-for-districts/

Ariely, D. (2011). The Upside of Irrationality. Harper Perennial.

Ariely, D. (2013). The Honest Truth About Dishonesty: How We Lie to Everyone-Especially Ourselves. Harper Perennial; Reprint edition.

Banerjee, A. (1992). A simple model of herd behavior. Quarterly Journal of Economics, $107,797-817$.

Barshay Jill (2019). What 2018 PISA international rankings tell us about U.S. schools

Results point to achievement gaps inside each school. https://hechingerreport.org/what-2018-pisa-international-rankings-tell-usabout-u-s-schools/

Behavioral Insights Team. (2018). About Us. http://www.behaviouralinsights.co.uk

Behavioral Economics. (2020). Resources. https://www.behavioraleconomics.com/

BEworks (Dan Ariely, Kelly Peters, and Nina Mažar) (2020). How Do We Work? ( $\underline{\text { http://beworks.com/) }}$ 
How Can Behavioral Economics

Bettinger, E. P., Terry, B. Long, T., and P. Sanbonmatsu, O. L. (2012). The Role Of Application Assistance And Information In College Decisions: Results From The H\&R Block Fafsa Experiment.

Bikhchandi, S. Hirschleifer, D. and Welch, I. (1992). A theory of fads, custom and cultural change as informational cascades. Journal of Political Economy, 100, 992-1026.

https://cepa.stanford.edu/sites/default/files/Bettinger\%20Long\%20Oreopoulos\%

20Sanbonmatsu\%20-\%20FAFSA\%20paper\%201-22-12.pdf

Bridgeable (2017). Designing for Behavior Change Toolkit. https://toolkit.bridgeable.com/

BusinessInsider (2016). The latest ranking of top countries in math, reading, and science is out and the US didn't crack the top 10 http://www.businessinsider.com/pisa-worldwide-ranking-of-math-sciencereading-skills-2016-12

Connolly, T. and Dean, D. (1997). Decomposed Versus Holistic Estimates of Effort Required for Software Writing Tasks. Management Science, 1029 - 1045

Cheeseman Day, Jennifer, L. Eric C. Newburger. (2014). The Big Payoff: Educational Attainment and Synthetic Estimates of Work-Life Earnings." United States Census Bureau. Accessed February 26, https://www.census.gov/prod/2002pubs/p23-210.pdf.

Daly, S.R., Yilmaz, S., Christian, J. L., Seifert, C. M. and Gonzalez, R. (2012). Design Heuristic in Engineering Concept Generation. Journal of Engineering Education, 101 (4), 601-609.

Damasio, Hanna \& J. Grabowski, Thomas \&Tranel, Daniel and D. Hichwa, Richard \& R. Damasio, A. (1996). A Neural Basisfor Lexical Retrieval. Nature, 380. 499505.

de Bono, E. (1975). The uses of lateral thinking. New York: Harper and Row.

de Bono, E. (1992). Six thinking hats. Des Moines, Iowa: Advanced Practical Thinking Training.

Dhami, S. (2017). The Foundations of Behavioral Economic Analysis. Oxford University Press; 1 edition.

Edweek (2020). Design and Behavior. www.blog.edweek.org

FehrAdvice \& Partners. 2018. About Us. https://fehradvice.com/ 
Goldstein, Dana (2019). It Just Isn’t Working': PISA Test Scores Cast Doubt on U.S. Education Efforts. The New York Times. https://www.nytimes.com/2019/12/03/us/us-students-international-testscores.html

Heskett, J. (2017). Design and the Creation of Value, ed. Clive Dilnot and Suzan Boztepe London: Bloomsbury.

Ideas42. 2019. Behavioral Economics Approach. www.ideas42.org

Johnson, E. J., and Goldstein, D. (2003). Do Defaults Save Lives? Science, 302 (5649), 1338-1339.

Kahneman, D., and Tversky, A. (1979a). Prospect Theory: An Analysis of Decision under Risk. Econometrica, 47(2), 263-291.

Kahneman, T., and Tversky, A. (1979b). Intuitive Prediction: Biases and Corrective Procedures.

Kahneman, D. (2013). Thinking Fast and Slow. Farrar, Straus and Giroux.

Kearon, J., Wood, O., and Ewing, T. (2017). System1 Unlocking Profitable Growth. System1 Group PLC. London: U.K.

Keller, P. A., Harlam, B., Loewenstein, G., \& Volpp, K. G. (2011). Enhanced active choice: A new method to motivate behavior change. Journal of Consumer Psychology, 21(4), 376-383.

Kelley, T. and Kelley D. (2013). Creative Confidence: Unleashing the Creative Potential Within Us All. Kindle Edition, Currency; 1 edition.

Liedtka, J.M. and Ogilvie,T (2012). Helping Managers to Discover Their Appetite for Design Thinking. Design Management Review, 7-13.

Liedtka, J., Ogilvie, T., \& Brozenske, R. (2014). The Designing for Growth Field Book: A Step-by-Step Project Guide. Columbia Business School Publishing, New York.

Lissack, M. (2019). Understanding Is a Design Problem: Cognizing from a Designerly Thinking Perspective. She Ji: The Journal of Design, Economics, and Innovation, 5, 3, 232.

Luma Institute. (2012). Innovating for People Handbook of Human-Centered Design Methods. Luma Institute. 
How Can Behavioral Economics

Madrian, B. C. 2014. Applying Insights From Behavioral Economics To Policy Design

Annu Rev Economics, 6: 663-688.b

Miller,T. (2015). Partnering for Education Reform. US Department of Education.

Mullainathan, S., and Shafir, E. (2009). Savings policy and decision-making in lowincome households. In M. Barr \& R. Blank (Eds.), Insufficient funds: Savings, assets, credit, and banking among low-income households. Russell Sage Foundation Press (pp. 121-145).

Newell, A., and Simon, H. A. (1972). Human problem solving. Englewood Cli • s, NJ: Prentice Hall.

O'Dhaniel A. Mullette-Gillman ,Ruth L. F. Leong,Yoanna A. Kurnianingsih (2015). Cognitive Fatigue Destabilizes Economic Decision-Making Preferences and Strategies. PLOS ONE 10(9)

Poggenpohl S. H. (2017). Blindspots in Economics and Design: A Review of John Heskett's Design and the Creation of Value. She Ji: The Journal of Design, Economics, and Innovation, 3, I4, 251-261

Rankin, J. G. (2019). Behavioral Economics of the Mind on Design: Identity, Bias, and More. She Ji: The Journal of Design, Economics, and Innovation, 5, 4, 376-379

Rick, S. I., Cryder, C. E. and Loewenstein, G. 2008. Tightwads and spendthrifts. Journal of Consumer Research, 34, 767-782.

Roland G. Fryer, Jr, Steven D. Levitt, John List, Sally Sadoff. 2012. Enhancing The Efficacy Of Teacher Incentives Through Loss Aversion Field Experiment, Working Paper 18237http://www.nber.org/papers/w18237

Samson, A. 2014. A simple change that could help everyone drink less. Psychology Today. Retrieved from http://www.psychologytoday.com/blog/consumed/201402/simple-change-couldhelp-everyone-drink-less.

Schultz, P. Wesley, Jessica M. Nolan, Robert B. Cialdini,3 Noah J. Goldstein and Vladas Griskevicius. (2007).The Constructive, Destructive, and Reconstructive Power of Social Norms. Psychological Science, 8, 5.

Seifert, C. M., Gonzalez, R. Yilmaz, S., Daly, D. (2016).Boosting Creativity in Idea Generation Using Design Heuristic. Design Thinking: New Product 
Development Essentials From The PDMA. chapter 6, Ed. Luchs, Michael; Swan, Scott; Griffin, Abbie: Wiley, New Jersey.

Simon, H. A. (1976). Administrative behavior: A study of decision-making processes in administrative organization (3rd ed.). Free Press.

Iyengar Sheena S. and Mark R. Lepper (2000) When Choice is Demotivating: Can One Desire Too Much of a Good Thing? Journal of Personality and Social Psychology, 79, 6, 995-1006

Shih, M., Pittinsky, T. L., Ambady, N. (1999). Stereotype Susceptibility: Identity Salience and Shifts in Quantitative Performance.

Soman, D. (2015). The Last Mile: Creating Social and Economic Value from Behavioral Insights, University of Toronto Press.

\section{TGG Group. 2018. http://tgggroup.com/}

Thaler R. H. and Cass R. (2009). Sunstein Nudge: Improving Decisions About Health, Wealth, and Happiness. Penguin Books

Thomas, M., Desai, K. K., Seenivasan, S. (2011). How credit card payments increase unhealthy food purchases: Visceral regulation of vices. Journal of Consumer Research, 38, 505-524.

Tversky, A., and Kahneman, D. (1974). Judgment under uncertainty: Heuristics and biases. science, $185,4157,1124-1131$.

Wendel, S (2020). Designing for Behavior Change: Applying Psychology and Behavioral Economics. O'Reilly Media, Inc.

Wrigley, C. (2016). Design Innovation Catalysts: Education and Impact. She Ji: The Journal of Design, Economics, and Innovation, 2, 2, 148-165

Zaltman, G. (2003). How Customers Think: Essential Insights into the Mind of the Markets. Harvard Business School Press, Boston.

Zhou, R., \& Soman, D. (2003). Looking back: Exploring the psychology of queuing and the effect of the number of people behind. Journal of Consumer Research, 29(4), $517-530$. 
Annex

Annex Table 1. List of Behavioral Methods

\begin{tabular}{|c|c|}
\hline Anchoring & $\begin{array}{l}\text { The first fact, number, or figure a person hears will bias } \\
\text { their judgments and decisions down the line. }\end{array}$ \\
\hline Availability Bias & $\begin{array}{l}\text { People give undue weight to what easily comes to mind: } \\
\text { often vivid memories or recent events. }\end{array}$ \\
\hline Confirmation Bias & $\begin{array}{l}\text { People analyze and search for information in ways that } \\
\text { support their current ideas. }\end{array}$ \\
\hline Decision Paralysis & $\begin{array}{l}\text { When given many options, people make the easiest choice, } \\
\text { which is often no choice at all. }\end{array}$ \\
\hline Default Bias & $\begin{array}{l}\text { People pick the easiest option to avoid complex decisions. } \\
\text { Defaults provide a cognitive short-cut and signal what } \\
\text { people are supposed to do. }\end{array}$ \\
\hline Disposition Effect & $\begin{array}{l}\text { People have a habit of holding on to poor investments too } \\
\text { long and selling good investments too soon. }\end{array}$ \\
\hline Ego Depletion & $\begin{array}{l}\text { The ability to make good decisions is a limited resource } \\
\text { that can be drained by both decision overload and external } \\
\text { fatigue. }\end{array}$ \\
\hline Endowment Effect & People overvalue what they own. \\
\hline Friction Costs & $\begin{array}{l}\text { People can be deterred from taking action by seemingly } \\
\text { small barriers. }\end{array}$ \\
\hline Gamification & $\begin{array}{l}\text { People like to play games! They will go to great lengths } \\
\text { playing a game even if all they get are points. }\end{array}$ \\
\hline Goal Gradient & $\begin{array}{l}\text { People will work harder to achieve a goal as the goal gets } \\
\text { closer. }\end{array}$ \\
\hline Herding & People tend to do what others are doing. \\
\hline Hyperbolic Discounting & $\begin{array}{l}\text { People put an unrealistically high value on the here and } \\
\text { now and an unrealistically low value on the future. }\end{array}$ \\
\hline Identifiable Victim Effect & $\begin{array}{l}\text { One identifiable individual, who is described in great } \\
\text { detail, evokes deeper emotions and sympathy than does a } \\
\text { large group of anonymous individuals. }\end{array}$ \\
\hline Implementation Intentions & $\begin{array}{l}\text { People are more likely to do something when they specify } \\
\text { how, when, and where they will do it. }\end{array}$ \\
\hline Lack of Self-Control & People have a hard time delaying gratification. \\
\hline Loss Aversion & $\begin{array}{l}\text { People react to losses more strongly than gains and they } \\
\text { try to prevent losses more than they try to make gains. }\end{array}$ \\
\hline Mental Accounting & $\begin{array}{l}\text { People categorize and spend money differently depending } \\
\text { on where it came from and where it is going. }\end{array}$ \\
\hline Money Illusion & People confuse actual dollar amounts with the buying \\
\hline
\end{tabular}


Davranışsal Beyin Fırtınası: Davranışsal İktisat İnovasyona Nasıl Katkıda Bulunabilir? 5-Adım-Metodu

\begin{tabular}{|c|c|}
\hline & power of dollars. \\
\hline Omission Bias & $\begin{array}{l}\text { People consider harmful actions worse than equally } \\
\text { harmful inactions. }\end{array}$ \\
\hline Opportunity Cost Neglect & $\begin{array}{l}\text { People tend to ignore what they give up when they make } \\
\text { decisions. }\end{array}$ \\
\hline Optimism Bias & $\begin{array}{l}\text { We overestimate the probability of "things going right for } \\
\text { us" and underestimate the probability of "things going } \\
\text { wrong for us". }\end{array}$ \\
\hline Ostrich Effect & $\begin{array}{l}\text { People who are worried they have fallen off track don't } \\
\text { want to know how they're doing. }\end{array}$ \\
\hline Overconfidence & $\begin{array}{l}\text { Everyone believes they are right, and everyone believes } \\
\text { they are above average. }\end{array}$ \\
\hline Pain of Paying & $\begin{array}{l}\text { Some purchases-such as incremental payments or paying } \\
\text { with cash-are more painful than others so people will } \\
\text { avoid them. }\end{array}$ \\
\hline Payment for Effort & $\begin{array}{l}\text { People place a greater value on services and products if } \\
\text { they can see the amount of effort put into them. }\end{array}$ \\
\hline Planning Fallacy & $\begin{array}{l}\text { When planning, people underestimate the resources } \\
\text { needed to meet their goals (such as time or level of } \\
\text { commitment). }\end{array}$ \\
\hline Power of Free & $\begin{array}{l}\text { A price of zero is psychologically much more attractive } \\
\text { than any other price, no matter how low. }\end{array}$ \\
\hline Pre-Commitment & $\begin{array}{l}\text { When people actively commit to a goal, they are more } \\
\text { likely to achieve it. }\end{array}$ \\
\hline Reciprocity & $\begin{array}{l}\text { People have an inherent desire to help those who have } \\
\text { helped them in some way. }\end{array}$ \\
\hline Regret \& Counterfactuals & $\begin{array}{l}\text { Satisfaction depends both on actual outcomes and ideas } \\
\text { about what could have happened. }\end{array}$ \\
\hline Relativity & $\begin{array}{l}\text { People evaluate options by comparing them to what else is } \\
\text { around. }\end{array}$ \\
\hline Reward Substitution & $\begin{array}{l}\text { Immediate rewards, which appeal to people's impulsive } \\
\text { nature, can be used to motivate behaviors that are } \\
\text { beneficial in the long run. }\end{array}$ \\
\hline Scarcity Mindset & $\begin{array}{l}\text { People who lack a resource, such as money, time, or } \\
\text { calories, tend to tunnel in on the scarce resource and carry } \\
\text { a larger cognitive load. }\end{array}$ \\
\hline Self-Herding & $\begin{array}{l}\text { People make decisions by asking themselves what they did } \\
\text { last time and assume what they already did must have been } \\
\text { a good idea. }\end{array}$ \\
\hline Self-Signaling & $\begin{array}{l}\text { People behave in ways that reinforce the type of person } \\
\text { they believe themselves to be, even if no one else is around } \\
\text { to witness it. }\end{array}$ \\
\hline Social Proof & $\begin{array}{l}\text { People want to be like everyone else and are heavily } \\
\text { influenced by what they perceive everyone else is doing. }\end{array}$ \\
\hline
\end{tabular}


How Can Behavioral Economics $\underline{\text { AKIN }}$ Contribute to Innovation? 5-Step-Method

\begin{tabular}{|l|l|}
\hline Status Quo Bias & $\begin{array}{l}\text { People are very committed to keeping things the way that } \\
\text { they are. }\end{array}$ \\
\hline Substitution & $\begin{array}{l}\text { It is easier for people to substitute a similar behavior than } \\
\text { to eliminate an entrenched one. }\end{array}$ \\
\hline Tunneling & $\begin{array}{l}\text { When faced with an emergency, people can only focus on } \\
\text { the emergency. }\end{array}$ \\
\hline What-the-hell Effect & People give up on their goals once they've fallen off track. \\
\hline $\begin{array}{l}\text { You Are What You } \\
\text { Measure }\end{array}$ & $\begin{array}{l}\text { People repeat behaviors that are rewarded, regardless of } \\
\text { whether those behaviors lead to success. }\end{array}$ \\
\hline
\end{tabular}

Source: Common cents lab 